\title{
ALTA INCIDÊNCIA DE Tomato chlorotic spot virus EM JILÓ NO ESTADO DE SÃO PAULO
}

\author{
LUIZ C. RABELO ${ }^{1}$, DANILO S. PEDRAZZOLI ${ }^{1}$, QUELMO S. NOVAES ${ }^{1}$, TATSUYA NAGATA ${ }^{3}$, JORGE A.M. \\ REZENDE $^{1}$ \& ELLIOT W. KITAJIMA ${ }^{2}$
}

\author{
${ }^{1}$ Dept. Entomologia, Fitopatologia e Zoologia Agrícola, ESALQ/USP, 13418-900 Piracicaba, SP; ${ }^{2}$ NAP-Microscopia \\ Eletrônica, ESALQ/USP, 13418-900 Piracicaba, SP, ${ }^{3}$ Dept. Biologia Celular, UNB, 70919-970 Brasília, DF
}

(Aceito para publicação em 26/07/2001)

Autor para correspondência: Jorge A.M. Rezende

\section{ABSTRACT \\ High incidence of Tomato chlorotic spot virus in Solanum gilo in the State of São Paulo, Brazil}

Biological, serological and electron microscopy assays confirmed the presence of Tomato chlorotic spot virus (TCSV) infecting Solanum gilo in commercial plantations in the State of São Paulo.
O jiló (Solanum gilo L.) é uma hortaliça anual de porte herbáceo, pertencente à família Solanaceae, cuja produção parece estar limitada à cultivar Morro Grande (Estado de São Paulo), cultivar Comprido Verde (Estado do Rio de Janeiro) e cultivar Tinguá (Estado de Minas Gerais). O cultivo ocorre no período de agosto a março, sendo a espécie bastante sensível ao frio. No litoral, pode ser cultivado o ano todo. Plantio comercial de jiló, cultivar Morro Grande, no município de Taiaçú, SP, foi inspecionado devido à presença de grande número de plantas com sintomas típicos daqueles causados por vírus. As plantas exibiam mosaico foliar acompanhado de bolhas e manchas amarelas nos frutos (Figura $1 \mathrm{~A}$ e B). Em alguns casos notou-se também a presença de anéis nos frutos. Em um lote com 423 plantas, escolhidas ao acaso no meio da plantação, 144 apresentavam sintomas da doença. Extrato de folhas de planta sintomática foi inoculado mecanicamente nas seguintes plantas-teste: Chenopodium amaranticolor Coste \& Reyn; C. quinoa Willd; Datura stramonium L.; Nicotiana benthamiana L.; N. glutinosa L.; N. tabacum L. cv. Samsum; $N$. tabacum cv. Rustica; N. tabacum cv. Xanthi; N. tabacum $c v$. Turkishi; além de jiló cv. Morro Grande. Os sintomas observados na amostra de campo foram reproduzidos nas plantas-teste de jiló, mantidas em casa de vegetação. Plantas de D. stramonium, $N$. tabacum $\mathrm{cv}$. Turkishi e $N$. tabacum $\mathrm{cv}$. Xanthi mostraram sintomas de lesões locais e invasão sistêmica; $N$. tabacum cv. Samsum apresentou somente lesão local, enquanto que $N$. benthamiana apresentou sintomas similares àqueles causados por espécies de tospovirus, tais como manchas cloróticas e necrose sistêmica. Exames de cortes ultrafinos de tecido foliar de $N$. benthamiana, experimentalmente inoculada pelo isolado do vírus de jiló, revelaram a presença de partículas isométricas, com envelope, com diâmetro de aproximadamente $80 \mathrm{~nm}$, indicando que a doença estava associada com um membro do gênero Tospovirus (Figura $1 \mathrm{C}$ ). Extratos de folhas de jiló, experimentalmente inoculados, foram submetidos a um teste de DAS-ELISA, utilizando-se anti-soro contra a proteína do nucleocapsidio das seguintes espécies de tospovirus: Tomato spotted wilt virus (TSWV), Tomato chlorotic spot virus (TCSV), Groundnut ringspot virus (GRSV) e Chrysanthemum stem necrosis virus (CSNV). Os resultados desse teste indicaram que as amostras de plantas infectadas reagiram apenas com o anti-soro contra o TCSV. A ocorrência dessa espécie de tospovirus em jiló foi anteriormente relatada por Chaves et al., [Fitopatologia Brasileira 25 (suplemento):439. 2000] e a presente constatação indica que TCSV pode representar, em condições de campo, um importante fator de perda de produtividade desta hortaliça.

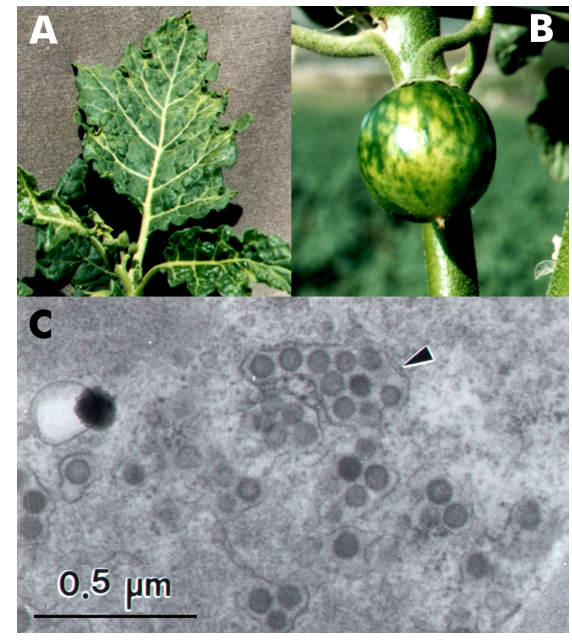

FIG. 1 - A - Folha de jiló (Solanum gilo) com mosaico e bolhas; B - fruto de jiló com manchas amarelas e C - micrografia eletrônica de transmissão, de secção ultrafina de célula do parênquima foliar de Nicotiana benthamiana experimentalmente inoculada com Tomato chlorotic spot virus isolado de jiló. As partículas virais encontram-se no lume do retículo endoplasmático (seta). 